2014, volume 3, issue 1

Kołosowska B., Voss G. (2014). Real options in the assessment of the company's pro-ecological investments. Copernican Journal of Finance \& Accounting, 3(1), 83-95. http://dx.doi.org/10.12775/CJFA.2014.007

\author{
Bożena KoxosowsKa* \\ Nicolaus Copernicus University
}

\author{
Grażyna Voss* \\ Torun School of Banking
}

\title{
AUTHORISED ADVISER - AS A COMPANY OF PUBLIC TRUST IN THE NEWCONNECT OTC (OVER-THE-COUNTER) EXCHANGE
}

Keywords: auditing, ethical standards, abuse of.

\section{J E L Classification: G180.}

Abstract: The paper notices that Authorised Advisers play the role of internal auditors in the companies listed on the NewConnect market. In principle, the issuers are small and medium enterprises who expect adequate support and help. The advisers who are responsible for proper introduction and servicing of the companies on the market must of course be subject to appropriate legal regulations. Yet, as a rule, the Over-The-Counter market of small and medium enterprises' stocks is subject to certain simplifications which cause that not all of the issues regarding the responsibility of Authorised Advisers have been regulated. The introduction of more detailed regulations contributes to increasing the transparency of the market and to assuring greater safety for its participants, and unethical behaviours eliminate the entities which should have not been present in the list of authorised advisers.

Date of submission: March 3, 2014; date of acceptance: March 23, 2014.

* Contact information: bozkolos@umk.pl, Department of Finance Management, Faculty of Economic Sciences and Management, Nicolaus Copernicus University, Gagarina 13a, 87-100 Toruń, Poland, phone: 566114899.

** Contact information: gvoss@wp.pl, Department of Accounting, Torun School of Banking, Młodzieżowa 31a, 87-100 Toruń, Poland, phone: 691372808. 


\title{
AUTORYZOWANY DoRADCA - JAKo SPÓŁKA ZAUFANIA PUBLICZNEGo NA ALTERNATYWNYM RYNKU OBROTU GIEEDOWEGO NEWCONNECT
}

Słowa kluczowe: audyt, standardy etyczne, nadużycia.

Klasyfikacja J E L: G180.

\begin{abstract}
Abstrakt: W artykule dostrzegamy, iż Autoryzowani Doradcy pełnią rolę audytorów wewnętrznych w spółkach notowanych na NewConnect. Z założenia emitentami są małe i średnie przedsiębiorstwa, które oczekują odpowiedniego wsparcia i pomocy. Doradcy odpowiadając za prawidłowe wprowadzenie i obsługę spółek na rynku muszą oczywiście podlegać odpowiednim regulacjom prawnym. Jednakże z założenia alternatywny system obrotu akcjami małych i średnich przedsiębiorstw podlega pewnym uproszczeniom, które powodują, iż nie wszystkie kwestie dotyczące odpowiedzialności Autoryzowanych Doradców zostały jeszcze uregulowane. Wprowadzanie coraz bardziej szczegółowych przepisów przyczynia się do zwiększenia przejrzystości rynku oraz do zapewnienia większego bezpieczeństwa jego uczestnikom, a nieetyczne zachowania eliminują podmioty, które nie powinny pojawić się na liście autoryzowanych doradców.
\end{abstract}

Translated by Bożena Kołosowska, Grażyna Voss

\section{INTRODUCTION}

The profession of an auditor reaches back into the ancient history and its origin is estimated for approx. $3000 \mathrm{BC}$ and relates to the civilizational development of Mesopotamia. The need of introducing control became the answer to the growing need for such type of supervision in the Mesopotamian mansions and estates. At that time, the internal control applied was based on marks, dots and dashes.

As a result of development over thousands of years, two types of audit can be distinguished: the so-called business audit, i.e. external and internal (Moeller 2011,25). External auditor is a statutory auditor who in many countries obtains his authorisations issued by a national authority and is included in an appropriate professional registry. The external auditor carries out examinations of the financial reports presented by a business unit and expresses his/ her opinion together with publishing a report.

An internal auditor is an employee of the company and he/she carries out independent examination in the scope of applying correct procedures, both in the area of finance and the operational activities of the enterprise. In its simplest form, the internal audit takes place when an employee reviews the carried out actions in order to find out whether these could be carried out "more effi- 
ciently or better". By engaging more people, or an external company, in these activities, the audit becomes broadened with the evaluation by given persons of certain tasks, taking into account the correctness and effectiveness of the performed tasks. In small enterprises the owner can carry out such a review of actions by himself, but when the business unit is complex and covers many areas of activities, it is worth to commission such reviews to specialised and adequately prepared employees.

In modern understanding, the internal audit fulfils a role of evaluating the mechanisms of the management control and has an advisory function. The internal audit focuses on the shortcomings of the systems' functioning and also on advising and supporting the management staff in the scope of operational control's effectiveness and efficiency (Winiarska 2013, 17).

\section{THE RESEARCH METHODOLOGY AND THE COURSE OF THE RESEARCH PROCESS}

The aim of this paper is to present the role an Authorised Adviser fulfils in the process of introducing companies to the market in the Over-The-Counter (OTC) exchange, fulfilling the companies' information duties and advising them on the functioning of the instruments in this system. The paper also showcases the importance of ethical behaviour regarding the entities joined through this exchange - issuers, investors and the OTC organiser, who is the Warsaw Stock Exchange; and whether the regulations of "Good Practices of the Authorised Advisers in NewConnect OTC" constitute legal protection against the occurring improprieties.

The basic methods used in the process of writing of this report were: analysis and critical assessment of legal acts, the literature, the available studies carried out also by other authors, and relating to the study area. The design of the series, postulates method was also used deduction.

\section{CAUSES OF INTERNAL AUdiT'S DEVELOPMENT IN THE $20^{\text {TH }}$ CENTURY}

It should be noted that the development of internal audits in the ancient times was serving different objectives than the ones faced by internal auditors at the beginning of the $20^{\text {th }}$ Century. The perception of internal auditors changed significantly in 1934 when the Securities and Exchange Commission (SEC) was created in the United States (www.sec.gov). The effects of the Great Depression of 1930 s caused that the actions carried out by the SEC lead to the requirement 
of financial reports being examined by independent external auditors. The requirements introduced by the SEC also obliged the companies to appoint internal audit cells in which the applied procedures have significantly increased the trust of investors in the issuers emerging on the stock exchange.

The tasks of internal auditors in the first half of the $20^{\text {th }}$ Century included, among others, to carry out examinations in order to identify errors in accounting (Meigs 1960, 377). In 1942 the IIA (Institute of Internal Auditors) was established in New York, which supported internal auditors in their professional development and which in time became an international organisation. In the 1990s the companies working in the field of external audit (in the scope of financial reports) also begun to take on some of the duties of internal audits (regarding financial audit). In American companies this idea was very much supported by the management staff. Initially the IIA was against such solutions, but the problem of outsourcing came into existence after the bankruptcy of Enron, where the whole internal audit department was moved to an auditing company A. Andersen. The occurring conflict of interest introduced changes and in the process of internal audit it was decided that the company of the statutory auditor cannot simultaneously offer internal audit services (SOK). The solution which separates the internal audit and requires it not to be joined with the external audit is in place until today.

In the Polish economy the internal audit is of an optional character, but according to the Public Finance Act the duty of audit occurs only in the units within the public finance sector (Kołosowska B., Bartoszewicz A. (2014) Art. 272-296, Chapter VI of the Act from 27 August 2009 on Public Finance). In this paper we pay special attention to the Authorised Adviser, who plays a very important role in the whole process of introducing the company to the OTC NewConnect exchange, in the company fulfilling its information duties and in the whole process of its instruments' functioning within the OTC. The adviser is an investment company or another entity offering services related to economic trading, including financial advice, legal advice or financial audit. The adviser needs to be registered on the list kept by the organiser of the Over-The-Counter (OTC) exchange, who is the Warsaw Stock Exchange (http://www.ipo.pl).

\section{ETHICAL NORMS IN INTERNAL AUDIT}

The rules of ethical behaviours have been subject of interest for centuries and reach back to the ancient times. The history knows many cases of falls states, 
financial crises and bankruptcy of stock companies caused by the lack of ethical behaviour in their management (Sawicki 2013, 239). Integrity and ethical values are defined by the top management. We can state, that the economic unit which prepared an ethical code and has all of its employees adhering to this code, has an adequate set of values. Such code can be an important element of control. In case if the code is not adhered to or its rules are being broken as a result of a lack of knowledge or deliberate actions, the surrounding of such enterprise is in the danger of an increased level of risk as a result of the dishonesties taking place. It can also happen, that the employees are partially unaware that their behaviour is against the interests of their company.

Each profession requires the worker to adhere to the generally accepted professional standards, for internal auditors these are the International Professional Practices Framework for Internal Auditors, issued by the Institute of Internal Auditors, the so-called IIA Framework. Furthermore, the Institute has prepared the Auditor's Ethical Code, which aims at promoting ethical rules of conduct that include integrity, objectivity, confidentiality, professionalism (www.iia.org.pl).

\section{THE ROLE AND TASKS OF INTERNAL AUDIT}

The word "audit" comes from Latin and means to listen to, to interrogate, to examine. In Poland, audits were used in the 1990s in relation to verification of financial reports. Within internal audit the literature most often distinguishes financial, operational and IT audits. This classification can be broadened with financial, activity, system and compliance audits (Winiarska 2005, 33). The units taking advantage of internal audits should begin its planning from the analysis of the unit's needs, as this is the only way in which conducting the audit will lead to reaching the planned objectives.

At present the internal audit can be distinguished by characteristic features which are presented in Table 1.

Table1. Characteristic features of internal audit

\begin{tabular}{|l|l|}
\hline \hline \multicolumn{1}{|c|}{ Audit criterion } & \multicolumn{1}{c|}{ Internal audit } \\
\hline \hline Objective & Added value to the unit \\
\hline Scope & All of the unit's activities \\
\hline Period examined & Present state and future state \\
\hline
\end{tabular}




\begin{tabular}{|l|l|}
\hline \multicolumn{1}{|c|}{ Audit criterion } & \multicolumn{1}{c|}{ Internal audit } \\
\hline \hline Frequency & According to the schedule, throughout the year \\
\hline Knowledge of the unit & Knows the unit (as an employee) \\
\hline Examining entity & Auditor employed in the unit, contractor - external unit \\
\hline \hline
\end{tabular}

S o u r c e : authors' own study based on: Kiziukiewicz 2013, 16.

It is assumed, that due to the internal audit, the head of the unit is able to verify whether the objectives of the entity are realised in the correct way, the rules and procedures resulting from different requirements of the law in force are implemented and obeyed, and the implemented management control system works in a relevant, effective and efficient way, allowing to evaluate the activities of the enterprise in an adequate way. A system created in such way allows guaranteeing, that the processes taking place in the entity are relevant and efficient and allowing the unit's activities to be evaluated in an adequate way (Bartoszewicz 2011, 14).

\section{JOINT-STOCK COMPANIES LISTED IN NEWCONNECT}

As a part of the Polish public secondary financial market one can distinguish a dealing market organised by both regulated and Over-The-Counter dealing system, with the latter consisting of the electronic platform for government bonds and securities and the NewConnect organised by the Warsaw Stock Exchange. The regulated market includes the stock market in the form of Warsaw Stock Exchange, OTC wholesale bonds market run by BondSpot (previously CeT0) and the commodity market of financial instruments (Kudła 2011, 19). Transaction taking place at this exchange are usually made electronically using various telecommunication means (Jajuga 2006, 6).

The essence of the OTC stock exchange in Poland is to allow capital support for the companies in the very early or late phases of their life cycles. The financing should be used most of all for innovative projects. The creators of the present regulations noticed the capital limitations existing in small and medium enterprises with great development and innovation potential. It was for them that a platform was created that allows trading stocks which is of supplementary character to the Warsaw Stock Exchange. It can be an intermediary stage for those companies entering the main market, after their strengthening and reaching appropriate value. 
Issuing of stocks by the NewConnect market can be seen as a modern way of obtaining capital by small and medium enterprises. It is an alternative source of obtaining development funding, aside from bank loans, leasing, venture capital funds and business angels. What is very important from the point of view of the finances of the enterprise, apart from gaining access to capital, is that it allows the first market valuation of the company's own capital. Apart from allowing access to new capital resources, starting listing on the NewConenct also allows to be featured in the media, daily reporting their current financial quotations. By applying good practices and absorbing modern ways of managing companies, the companies listed at the exchange gain experience in investor relations. Reaching a broad spectrum of investors relates to an increase in the company's credibility among its contractors and financial institutions. It also allows creating relevant tools for evaluating employees as a part of the already existing system of employee motivation ${ }^{1}$. Such companies then gain various benefits resulting from being listed in the NewConnect market, with significantly limited capital resources and lower formal requirements in relation to the companies listed at the Warsaw Stock Exchange. The companies also benefit from lower reporting costs, lower audit costs, and less rigid requirements of introduction and listing at the Over-The-Counter (OTC) exchange.

The information materials on NewConnect point out, that this market was planned for newly-established companies with capital not exceeding 20 Million Euro, with a very big development potential. It was assumed that the companies will be emitting between several hundred thousand to a dozen or so million Zloty (www.newconnect.pl) The companies were to belong to resilient innovative sectors based on immaterial assets (e.g. IT, electronic media, telecommunication, biotechnology, environmental protection, alternative energy, state-of-the-art scientific and technological thought) (Banaszczak-Soroka 2012, 86-87).

The investors point out to the significantly greater risk of investing in stocks of companies that only start their business activities, implementing projects which may yield benefits only in the future. This also shows that the in-

1 The system of awarding bonuses to the key employees can be dependent on the increase of the stocks' price, and the company can also intoroduce the possibility of awarding the employees with the company's stocks depending on maintaining the adequately high level of the activities' results (often reliant on the increase of the company's value in the future, or maintaining the adequate levels of the ECA, MVA or ROIC indicators). 
vestors can be the pioneers in financing innovative projects, branches or solutions which are deemed too risky by the traditional suppliers of capital, such as banks ${ }^{2}$. These points will be subject of evaluation included in chapter four of this paper. Now we shall move on to the characteristics of bonds and searching for the answer to the question whether obtaining capital through emitting corporate bonds could become an attractive source of financing business activities of small and medium enterprises.

Before a company is permitted to trade, a contract is signed between an authorised adviser and the market animator or the Market Maker. The organiser of the Over-The-Counter exchange keeps separate lists of Authorised Advisers for the NC and Catalyst markets, and individual advisers can be featured on both lists (www.newconnect.pl).

Their functions, tasks, possible penalties and exclusions were defined. Among other tasks, the Authorised Adviser takes on converting the issuer into a public company, takes all due diligence in taking care of the reliability and completeness of information presented in the information document, which is created based on the requirements of the current law and the market's best practices. The actions also include cooperation with companies listed on the market in the scope of their fulfilment of information duties, monitoring the correctness of securities' sales, and offers advisory services regarding trading stock at the NC market (Kołosowska 2013, 123).

From the perspective of several years that the NC market has been functioning, it can be observed that there have been certain improprieties in that the Authorised Adviser has been remunerated by taking over stocks of the enterprise she/he has been servicing. This causes significant imbalance in the correctness of valuing the company - in case when the adviser is directly interested in leading the offer of stocks' sales. In 2012 GOADVISERS - one of the highest-ranked advisory companies on this market, has been removed from the list of advisers. It was accused of making errors during the preparation of information documents for one of the companies introducing its stocks to the NC. The occurring conflict is very often irreconcilable, because "the ethical duty of the adviser is also to absolutely inform of possible dependencies of his remu-

${ }^{2}$ More on the functioning of the NC market: M. Buszko (2010), NewConnect - nowy rynek wspomagający rozwój małych i średnich przedsiębiorstw w Polsce [in:] Przedsiębiorstwa i instytucje w warunkach kryzysu finansowego., Zeszyty Naukowe nr 593. Problemy zarządzania, finansów i marketingu, Wyd. Nauk. Uniwersytetu Szczecińskiego, Szczecin, 21-32. 
neration on the value of the obtained capital, as pointed out by the practitioners" (http://grupatrinity.pl/pressroom/publikacje.html).

According to the requirements of the Over-The-Counter exchange, the entities who can become Authorised Advisers are: "investment companies or other entities which are companies regulated by the trade law, as long as the entity or its legal predecessor have been offering services relating to economic trading on the financial market, including financial advising, legal advising or financial audit for at least 2 years, on the condition that it fulfils the requirements defined in the Over-The-Counter Regulations, if in the assessment of the Organiser of the Over-The-Counter exchange such entity provides a pledge of correct performance of the actions of an Authorised Adviser" (www.newconnect.pl).

The "Good Practices of Authorised Advisers in NewConnect" have been prepared and entered into force on $1^{\text {st }}$ January 2009 in a form of recommendations. In relation to the Authorised Advisers a requirement was introduced to include information of applying the Good Practices in their annual report. It is assumed that this will increase the standards of behaviour among the Authorised Advisers in NewConnect. This way will create adequate conditions supporting this market's development and assure the security of functioning for the companies that are the issuers on the market. This will also increase the reliability of the published information, which is what the individual investors, who are the main investors in NewConnect, pay special attention to.

What is also emphasised when evaluating the work of the advisers is, that they are responsible that the issuers, which each of the advisers services, adhere to the information requirements; service the stocks introduced in the OTC; carrying out advisory actions. In the year 2013 the period of signing the contracts with the advisers was extended to 3 years, as it was decided that the help to the issuers should be offered for a period longer than one year as it was defined in the previous regulations. Companies listed in the NC require help not only with fulfilling their duties, but also because their actions should lead to an increase in their company's stocks. Therefore it is necessary to present their achievements in a reliable manner and also frequently. This causes the advisers to become speakers for their companies. Special attention is paid to the quality of offered services and to blameless opinion. However, the assessments tend to differ - in the year 2014 the Warsaw Stock Exchange has excluded out of the list of authorised advisers 4 entities servicing NewConnect companies, 13 warning notices admonitions have been issued and one financial penalty was given in the amount of 20,000 PLN. 
Table 2. List of sanctions issued by the Organiser of OTC for the Authorised Advisers in NewConnect

\begin{tabular}{|c|c|c|c|c|c|}
\hline \hline Year & Total & $\begin{array}{c}\text { Removal from } \\
\text { the AA list }\end{array}$ & $\begin{array}{c}\text { Warning } \\
\text { notice }\end{array}$ & $\begin{array}{c}\text { Financial } \\
\text { penalty }\end{array}$ & $\begin{array}{c}\text { Temporary suspension of the right } \\
\text { to act as an Authorised Adviser. }\end{array}$ \\
\hline \hline 2009 & 1 & & & & 1 \\
\hline 2010 & 1 & & & & 1 \\
\hline 2012 & 1 & 1 & & & 1 \\
\hline 2013 & 18 & 4 & 13 & 1 & \\
\hline \hline
\end{tabular}

S o u r c e :http://www.newconnect.pl/pub/dokumenty_do_pobrania/kary/NEWCONNECT_zestawienie_kar_AD_29112013.pdf (accessed: 14.12.2013.).

When assessing the data included in Table 2 it can be observed, that there has been a significant increase in the number and severity of the sanctions issued against Authorised Advisers in the last year. There are no more temporary suspensions in rights to act as an Adviser, but there are removals from the list and warning notices. The following companies have been removed from the list of Authorised Advisers in the years 2013-2009 on the grounds of neglecting their activities relating to information documents and introducing stocks of chosen companies: CAPITAL CITY Sp. z o.o., IPO S.A., Capital Kopernik S.A.. The company DOM INWESTYCYJNY TAURUS S.A. has been partially suspended in its actions in 2012 due to the lack of possibilities of further adequate performance of Authorised Adviser's duties on the NewConnect and Catalyst markets, because of the company's legal and financial situation. The company GoAdvisers S.A. has been removed from the list of Authorised Advisers for improper conduct of the Authorised Adviser's duties, as the company: Kancelaria Ruciński i Wspólnicy, KLAUDIUSZ WOLNY EKSPERT has been suspended (http://www.newconnect.pl). Although these may seem like individual cases, with companies of public trust this should not happen at all. This undermines the sense of more liberal solutions relating to the OTC market applied to small and medium companies which look for comprehensive help from an authorised adviser.

The cases of negative effects of disdaining the rules of ethics indicate a need of a broad application of ethical standards in the economic life. There are, however, many causes holding back the process of disseminating the awareness of ethics and its application in practice. Such causes can include (Karmańska 2005, 139): 
- world-wide moral crisis,

- people have pushed the ethics to the background of their value system,

- ethics is becoming an uncomfortable limitation in many areas,

- creation of standards of actions without adhering to the rules of ethics or with a serious breach of those rules in the name of particular commercial interests.

Despite many imperfections in the functioning of economic unit it has to be observed, that the auditor's work results in recommendations which should become guidelines allowing the unit's functioning to improve. The objective of such recommendations is to neutralise the possibilities of significant risks, to improve the management system, and to assure that the set objectives and tasks will be realised in a defined period of time in a way that is effective and coherent with ethical standards (Sołtyk 2013, 276).

\section{CONCLUSIONS RESULTING FROM THE RESEARCH PROCESS}

Analyzing the results of published studies on the causes of the collapse of listed companies it should be noted that the elimination of these units can be attributed to actions of certain persons, that stand in contradiction to business ethics. Cases of negative effects of disregarding moral norms indicate the need for broad application of ethical standards in business life. Among elements of strengthening and utilizing of ethical principles in business there are procedures used in internal audit, which can help reduce irregularities and can be a source for standards based on good business practices and in accordance with ethical standards.

Internal audit is an independent and objective tool used for evaluation of the unit's management processes. It aims at bringing added value to the unit and improve its functioning. It also supports the unit in achieving its objectives and improving the efficiency of risk management, control system and management processes. Unethical behavior of persons owning or managing business entities cannot be totally eliminated with certanity but, by the existence of authorized advisers, can be significantly reduced. Unfortunately, it will also depend on the professional standards of good practices and personal responsibility of the people they employ. 


\section{REFERENCES}

Banaszczak-Soroka U. (2012), Rynki finansowe - organizacja, instytucje, uczestnicy, Wydawnictwo C.H. Beck, Warszawa, 86-87.

Bartoszewicz A. (2011), Praktyka funkcjonowania audytu wewnętrznego w Polsce, CeDeWu, Warszawa, 14.

Gabryel T., Doradztwo Ekonomiczne - Dariusz Zarzecki, http://grupatrinity.pl/pressroom/publikacje.html (accessed: 18.06.2013).

Gerakos J., Lang M., Maffett M. (2011), Listing Choices and Self-Regulation: The Experience of the AIM, The University of Chicago Booth Scholl of Business, Working Paper No. 11-04, Chicago, http://ssrn.com/abstract=1739137 (accessed: 14.03.2012). http://dx.doi.org/10.2139/ssrn.1739137.

Jajuga K. (2006), Rynek wtórny papierów wartościowych, KNF, Warszawa, 6.

Karmańska A. (2005). Etyka w dydaktyce rachunkowości. Zeszyty Teoretyczne Rachunkowości, 26 (82).

Kizukiewicz T. (2013), Audyt wewnętrzny w strukturze kontroli zewnętrznej, Difin, Warszawa, 16.

Kołosowska B. (2013), Finansowanie sektora małych i średnich przedsiębiorstw poprzez rynek kapitałowy w Polsce, CeDeWu, Warszawa, 123.

Kołosowska B., Bartoszewicz A. (2014), Art. 272-296 Dział VI. Audyt wewnętrzny oraz koordynacja audytu wewnętrznego w jednostkach sektora finansów publicznych, [in:] Ustawa o finansach publicznych, P. Smoleń (red.), CH Beck, Warszawa.

Kosiński K. (2013). Odnowa NewConnect od 1 czerwca. eBiuletyn NewConnect, nr 9.

Kudła J. (2011), Instrumenty finansowe i ich zastosowanie, Wydawnictwo Key Text, Warszawa, 19.

Meigs W. B. (1960). Professional examinations: Examination in auditing. Accounting Review, nr 2 (35), 377.

Moeller R. (2011), Nowoczesny Audyt wewnętrzny, Oficyna Wolters Kluwer business, Warszawa, 25.

Sawicki K. (2013), Problem etycznego postępowania w zakresie kontroli zarządczej, [in: ] Kontrola zarządcza oraz audyt wewnętrzny w teorii i praktyce, K. Winiarska (ed.), Wydawnictwo Uniwersytetu Szczecińskiego, Szczecin, 239.

Sołtyk P. (2013), Kontrola zarządcza i audyt w jednostkach samorządowych, C.H. BECK, Warszawa, 276.

Ustawa z dnia 27 sierpnia 2009 r. o finansach publicznych, Dz. U. z 2009 r. Nr 157, poz. 1240 i 1241 , z późn. zm.

Winiarska K. (2005), Teoretyczne i praktyczne aspekty audytu wewnętrznego, Difin, Warszawa, 33.

Winiarska K. (2013), Kontrola zarządcza oraz audyt wewnętrzny w teorii i praktyce, Uniwersytet Szczeciński, Szczecin, 17.

www.ipo.pl/new_connect/artykuly/rola_odpowiedzialnosci_i_etyki_zawodowej_w_pracy_autoryzowanego_doradcy_cz._1_592552.html (accessed: 20.01.2014). 
11. Authorised AdVISER - AS A COMPANy OF PUBLIC TRUST...

www.newconnect.pl/index.php?page=jak_zostac_autoryzowanym_doradca (accessed: 14.12.2013).

www.newconnect.pl/pub/dokumenty_do_pobrania/GPW_Przewodnik_NC.pdf (accessed: 20.12 .2013$)$.

www.sec.gov (accessed: 10.01.2014).

Załącznik Nr 5 do Regulaminu Alternatywnego Systemu Obrotu (według stanu prawnego na dzień 1czerwca 2013 r.) Autoryzowany Doradca w alternatywnym systemie obrotu, http://www.newconnect.pl/pub/regulacje_prawne/Regulamin_ASO_ UTP_zal_3.pdf (accessed: 12.06.2013). 
